\title{
The Effect of Interest in Becoming \\ a Sharia Bank Customer to Students of FEBI Universitas Suryakancana, Inonesia
}

\author{
Dadang Husen Sobana ${ }^{1 *}$, Melani Salsabila Anjani ${ }^{2}$ \\ ${ }^{1 *}$ Universitas Islam Negeri Sunan Gunung Djati Bandung, Indonesia \\ ${ }^{2}$ Universitas Suryakancana, Indonesia \\ *Corresponding Email: dadanghusensobana@uinsgd.ac.id
}

Keywords:

Motivation to Avoid

Riba, Product

Knowledge, Interest in Becoming a Customer

Kata Kunci:

Motivasi Menghindari

Riba, Pengetahuan

Produk, Minat

Menjadi Nasabah
Article Information Issue Hou To Cite
ABSTRACT

This research is motivated by the main problem which considers the concept of Islamic banks to be the hsame as conventional banks. This study aims to describe the effect of prevention and knowledge of Islamic banking products on the interest in becoming a customer of Islamic banks in FEBI students of the Surya Kencana University. The method used is descriptive with a quantitative approach. The population was $581 \mathrm{FEBI}$ students, so that the sample was taken by random sampling using the Slovin formula and obtained 86 respondents. The data analysis technique used multiple linear regression, coefficient of determination test, and hypothesis testing. The results of the study concluded that partially the motivation to avoid usury had an effect on the interest in becoming a sharia bank customer in FEBI students. No doubt with a contribution of $21.9 \%$. Then, knowledge of Islamic banking products affects the interest in becoming a customer of Islamic banks in FEBI Elements students with a contribution of $46.4 \%$. Simultaneously, avoiding usury and product knowledge have an effect on interest in becoming a sharia bank customer in FEBI Element students with a contribution of $68.3 \%$ with a strong coefficient proportion. While the remaining $31.7 \%$ is influenced by other factors outside the variables not examined with a low proportion coefficient.

\section{ABSTRAK}

Pengaruh Minat Menjadi Nasabah Bank Syariah pada Mahasiswa FEBI Universitas Suryakancana, Indonesia. Penelitian ini dilatarbelakangi oleh masalah utama yang menganggap konsep bank syariah sama saja dengan bank konvensional. Penelitian ini bertujuan untuk menganalisis pengaruh motivasi menghindari riba dan pengetahuan produk bank syariah terhadap minat menjadi nasabah bank syariah pada mahasiswa FEBI Universitas Suryakancana (Unsur). Metode yang dugunakan adalah deskriptif dengan pendekatan kuantitatif. Populasi terdapat sebanyak 581 mahasiswa FEBI, sehingga pengambilan sampel dengan random sampling dengan menggunakan rumus slovin dan didapatkan 86 responden. Teknik analisis data menggunakan regresi linear berganda, uji koefisien determinasi, dan pengujian hipotesis. Hasil penelitian menyimpulkan bahwa secara parsial motivasi menghindari riba berpengaruh terhadap minat menjadi nasabah bank syariah pada mahasiswa FEBI Unsur dengan kontribusi sebesar 21,9\%. Kemudian, pengetahuan produk bank syariah berpengaruh terhadap minat menjadi nasabah bank syariah pada mahasiswa FEBI Unsur dengan kontribusi sebesar 46,4\%. Dan secara simultan, motivasi menghindari riba dan pengetahuan produk berpengaruh terhadap minat menjadi nasabah bank syariah pada mahasiswa FEBI Unsur dengan kontribusi sebesar 68,3\% dengan proporsi koefisien kuat. Sedangkan sisanya sebesar 31,7\% dipengaruhi oleh faktor lain diluar variabel yang tidak diteliti dengan porporsi koefisien rendah.

Received: 14 October 2021; Revised: 10 December 2021; Accepted: 17 December 2021 Volume 1, Number 2, December 2021

Sobana. D. H., \& Anjani, M. S. (2021) Effect of Interest in becoming a Sharia Bank Customer to Students of FEBI Universitas Suryakancana, Indonesia. Talaa - Journal of Islamic Finance, 1 (2), 104-120 https://doi.org/10.54045/talaa.v1i2.350

2807-3002 / 2807-3312 
Sobana, D. H., \& Anjani, M. S. | Determinant of Interest_

\section{INTRODUCTION}

This research is due to the phenomenonwhere many people perceived conventional banks as more reliable than Islamic banks as they have been in existence earlier than Islamic banks, as well as how companies attract customers and maintain them so that the company can survive and grow.

Researchers captured a phenomenon where the objects of the study here areStudents of the Faculty of Economics and Islamic Business at Suryakancana Cianjur University (FEBI UNSUR). The main problem at the research site is despites the establishment of this Economics and Islamic Business faculty, it turns out that the the level of interest of students to become customers or even have a Sharia bank savings account is still minimal. Of course, this is contrary to theideals of FEBI students who supposed to uphold the value of Islamic economics coupled with knowledge due to the theoretical learning process in each course that should be implemented in Islamic financial institutions directly both after college and during their study. Those ideals include, being a customer of an Islamic bank, using the services of an Islamic bank, or working in an Islamic financial institution.

Several factors affect students' buying interest in Islamic bank products. One of the factors that support the background of FEBI students is related to the motivation to avoid riba. Riba here becomes the main topic of discussion in the learning process of Islamic Economics. It is also the main topic that distinguishes between Islamic banking and conventional banks. The motivation to avoid riba is an attitude or awareness that arises in the form of internal and external impulses in a person to avoid the danger of riba or bank interest that has been banned by Allah Swt. with the aim of initiating transactions that are halal and not contrary to islamic economic principles. FEBI students must be able to implement the knowledge that they have studied by implementing them into their daily economic activities in accordance with the rules of Islamic economic principles, one of which is becoming a customer of Islamic banks.

Another factor that can affects students' buying interest in Islamic banking products is product knowledge. The greater the knowledge of students, the higher the interest of students to become customers of Islamic banks by opening savings accounts at Islamic banks. Knowledge is an important factor for a person or society in making choices about things, including in determining the choice where they will leave funds. The knowledge possessed by FEBI students is considered to have great potential and has a fairly high opportunity compared to the knowledge of other students in fields outside islamic economics. The more knowledge about Islamic banks, the more students can perceive Islamic banks better and the higher the possibility to get in touch with Islamic banks.

Problems arise when the reality that occurs is not in accordance with the expectations and goals of educational institutions of the Faculty of Islamic Economics and Business, where reality shows that the ownership of Islamic bank accounts in students is still low. Compared to conventional bank account ownership in students tends to be high. This shows that the interest of Islamic economics students is still relatively low, it is a big question why this can happen in the Faculty of Islamic Economics and Business based on its operations and general view of the theory that all lecture activities are closely related to Islamic economic theory based on Sharia.

This becomes a core problem as a topic of this research, how this can happen in an institution based on sharia-based Islamic economics. To realize these goals, the right marketing strategy is needed, where the company is able to establish a marketing strategy that is on target, marketers must pay attention to consumer behavior well.

Several researchers have conducted research related to the same problem. (Samsudin ,2020), (Chalimi, 2020), (Irwanti, 2019), (Permana, Prastowo, \& Djaenudin 2021) conducted research with the same variables that are motivation to avoid riba. The result obtained is 
Sobana, D. H., \& Anjani, M. S. | Determinant of Interest_

motivation to avoid usury influence in the decision to become a customer at an Islamic bank. Then, product knowledge of the decision to become a customer is also influential based on research conducted by (Permana, Prastowo, \& Djaenudin 2021), (Samsudin, 2020), and (Chalimi, 2020).

This will review whether previous studies that have been done will prove influential if applied to different research objects, namely the students of FEBI Suryakancana University ofCianjur. Because considering the difference in background and geography will certainly affect the results. Looking at previous research that became dependent variables is the decision to become a customer while this research focuses on the interest of being a customer of Islamic bank in FEBI students. So the purpose of this article is to analyze the influence of motivation to avoid riba and knowledge of Islamic bank products on the interest of becoming a sharia bank customer in FEBI students of Suryakancana University.

\section{LITERATURE REVIEW}

\section{Islamic Bank}

Islamic Bank is a bank whose activities refer to Islamic law and in its activities do not charge interest or do not pay interest to customers. The share of islamic bank results received or paid to the customer depends on the agreement made by the customer and the bank. The agreement (akad) contained in Islamic banking must be subject to the terms and pillars of the agreement as stipulated in Islamic sharia (Andrianto \& Firmansyah, 2019).

Based on these description of the objectives of Islamic banks, it can be concluded that Islamic banks are presented today to direct the economic activities of Islamic believers. The main purpose of Islamic banks is to provide financial facilities by pursuing financial instruments in accordance with islamic sharia provisions and norms, one of which is to avoid the practice of riba (interest) by putting forward the principle of revenue sharing (Haryanti, 2020). In addition, Islamic banking aims to support the implementation of national development and.

\section{Riba}

Riba in language means: ziyyadah which means to grow, add, or excess (Firdaus, 2019). In another sense, linguistically riba also means growing and growing (Abdullah Saeed, 1996) in (Antonio, 2007). According to technical terms, riba means the additional taking of basic property or capital in vanity, either in buying and selling transactions, borrowing and in other forms (Suardi, 2019).

There are some opinions of experts on the definition of riba, but in general there is a common thread that asserts that riba is an additional takeover, both in buying and borrowing transactions (contrary to the principle of muamalah in Islam). Thus, although there are differences of opinion of experts about the definition of riba but the substance of the definition is the same. In general, the Muslim economist asserts that riba is an additional take that must be paid, both in buying and borrowing transactions that are contrary to sharia principles (Fauziah, 2021).

Thus it can be inferred from some differences of opinion of scholars in detailing the types of riba. But broadly speaking riba is divided into two parts, namely: riba about debts (Riba Qardh and Riba Jahiliyah); and riba about buying and selling (Riba Fadhl and Riba Nasi'ah). Riba practices that are often carried out by banks are riba nasi'ah and riba qardhi, sometimes in other transactions occur riba yadh or riba fadhl. A Muslim is obliged to stay away from the 
practice of riba, whatever the type of riba and whatever quantity of riba taken entirely is haram (Istiqomah, 2020).

\section{Motivation}

(Schiffman \& Kanuk, 2000) put forward "Motivation can be described as the driving force within individuals that impels them to action". Motivation is the driving force in a person that forces him to take action. While (Uno, 2021) said motivation is an internal situation that encourages the individual's desire to do certain desires to achieve a goal.

Many experts have expressed the notion of motivation with their respective points of view but the point is the same, namely as a driver that converts energy in a person into the form of real activities to achieve certain goals. Related to consumers (customers), motivation can be interpreted as an encouragement that moves consumers (customers) to decide to act towards achieving goals, namely meeting various needs and wants.

\section{Product Knowledge}

Product knowledge in Indonesian can be interpreted as knowledge owned by consumers about products / services to be consumed (Sari, 2020). Knowledge is influenced by several factors, one of which is experience (Bahlia, 2021). The more experience gained from ourselves and others, the more knowledge we gain. Likewise about product knowledge, the more knowledge and information about the product owned by consumers, the faster the consumer will decide the purchase of a product.

Product knowledge is a collection of various information about the product. This knowledge includes product categories, brands, product terminology, product attributes or features, product prices and trust regarding products (Prakosa \& Tjahjaningsih, 2021).

\section{Interest}

According to Schiffman and Kanuk, interest is a psychic activity that arises because of feelings and thoughts about a desired good or service. Consumers will be interested first will look for information that after that is followed by the decision to buy (Hermawanto \& Dadang, 2021).

The interest of being a customer in this case is assumed to be a buying interest, willingness to buy is part of the behavioral component in the attitude of consuming. Buying interest is the level of respondents' tendency to act before a decision is taken (Maulidya, Saroh, $\&$ Zunaida, 2021). There are two factors that affect buying interest, namely Environment and Stimulus marketing (Sandala, Tumbel, \& Tampenawamas, 2021). According to Ferdinan (2006) in (Purnawati, Mitariani, \& Anggraini, 2020) Buying interests can be identified through indicators namely Transactional Interests, Referential Interests, Preferential Interests, and Exploratory Interests.

\section{METHODOLOGY}

The design of this study uses multiple linear regression methods with descriptive and associative methods as well as quantitative approaches. The study was conducted at the Faculty of Islamic Economics and Business (FEBI) suryakancana Cianjur University with a student population of 581 people, with that number of researchers decided to use samples with random 
Sobana, D. H., \& Anjani, M. S. | Determinant of Interest_

sampling techniques which were then determined using the formula Slovin (Umar, 2008) with a tolerance of $10 \%$ significance. Thus obtained 86 respondents febi unsur students. Then, to obtain the research data, researchers collected data with observations, library studies, and questionnaires. In the implementation of this study, researchers distributed questionnaires to FEBI Suryakancana University'sstudents, where the preparation of measurement scales was used likert scale method and each respondent was asked for his opinion on a statement with a rating scale of 1 to 5 (Akdon, 2007). Data analysis uses quantitative methods that run validity test processes, reliability tests, classical assumption tests (multicollinearity tests, heteroskedasticity tests, and normality tests), autocorrelation tests, regression analysis, hypothesis tests ( $\mathrm{t}$ tests) and F tests) and model accuracy or goodness tests. the fit of a model, the coefficient of determination $\left(\mathrm{R}^{2}\right)$.

The variables used in this study are two, namely free variables (independent variables) and bound variables (dependent variables). Below, researchers describe the operational definition of these variables. The operational definition can be concluded is the description of each variable to its forming indicators.

Table 1: Operationalization of Research Variables

\begin{tabular}{|c|c|c|c|}
\hline Variable & Operational Definition & Indicators & Source \\
\hline $\begin{array}{l}\text { Motivation to } \\
\text { Avoid Riba } \\
\text { (X1) }\end{array}$ & $\begin{array}{l}\text { Motivation to avoid riba is a } \\
\text { motivational psychological factor } \\
\text { that will affect the choice of } \\
\text { purchasing of FEBI UNSUR } \\
\text { students towards an Islamic } \\
\text { banking product and service with } \\
\text { the aim of initiating transactions } \\
\text { that are more halal and not contrary } \\
\text { to islamic economic principles. }\end{array}$ & $\begin{array}{l}\text { 1. The Need for } \\
\text { Sharia Transaction } \\
\text { Recognition } \\
\text { 2. The need for his } \\
\text { wealth to be clean } \\
\text { from riba } \\
\text { 3. Knowledge of the } \\
\text { Dangers of Riba }\end{array}$ & $\begin{array}{l}\text { (Maslow\& } \\
\text { Antonio, } \\
\text { 2015) }\end{array}$ \\
\hline $\begin{array}{l}\text { Product } \\
\text { Knowledge } \\
(\mathrm{X} 2)\end{array}$ & $\begin{array}{l}\text { Product knowledge is a collection } \\
\text { of various information about a } \\
\text { product. The knowledge in } \\
\text { question is product knowledge } \\
\text { owned by all FEBI Suryakancana } \\
\text { University'sstudents. This } \\
\text { knowledge includes the } \\
\text { characteristics of Islamic bank } \\
\text { products, product transactions } \\
\text { used, product accounts used, } \\
\text { product classification and product } \\
\text { attributes. }\end{array}$ & $\begin{array}{l}\text { 1. Product Attribute } \\
\text { Knowledge } \\
\text { 2. Knowledge of } \\
\text { Product Benefits } \\
\text { 3. Product } \\
\text { Satisfaction } \\
\text { Knowledge }\end{array}$ & $\begin{array}{ll}\text { (Peter } \quad \& \\
\text { Olson, } \\
2010)\end{array}$ \\
\hline $\begin{array}{l}\text { Interest in } \\
\text { Becoming a } \\
\text { Customer }(\mathrm{Y})\end{array}$ & $\begin{array}{l}\text { Interest is the impulse or desire in a } \\
\text { person on a particular object } \\
\text { accompanied by feelings of } \\
\text { pleasure and thoughts towards a } \\
\text { desired good or service. In the } \\
\text { context of this research is reviewed } \\
\text { from the tendency of FEBI } \\
\text { UNSUR students who are }\end{array}$ & $\begin{array}{l}\text { 1. Transactional } \\
\text { Interests } \\
\text { 2. Referential Interests } \\
\text { 3. Preferential Interests } \\
\text { 4. Exploratory Interests }\end{array}$ & $\begin{array}{l}\text { Ferdinan } \\
\text { (2006) }\end{array}$ \\
\hline
\end{tabular}




\begin{tabular}{|l|l|l|l|}
\hline & $\begin{array}{l}\text { interested in becoming customers } \\
\text { of Islamic banks. }\end{array}$ & \\
\hline
\end{tabular}

.Based on the above explanation, it can be formulated that the models and hypotheses in this study are:

Figure 1: Research Framework Model

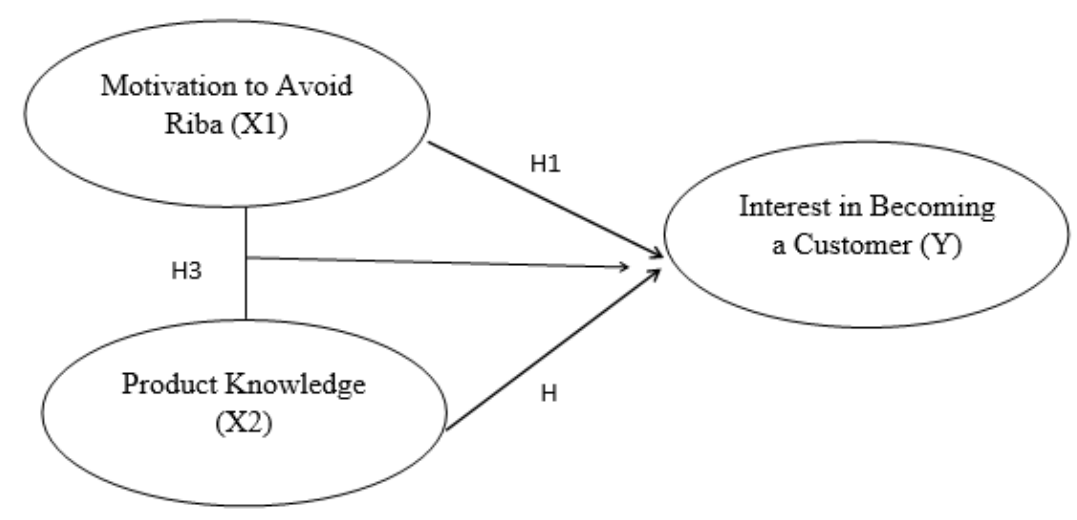
hypothesis

Referring to the model of the research framework above the researchers make a research

H1 : Motivation to Avoid Riba partially affects the Interest of Being a Customer

$\mathrm{H} 2$ : Product Knowledge partially affects the Interest of Being a Customer

H3 : Motivation to Avoid Riba and Product Knowledge simultaneously affect the Interest of Being a Customer

\section{RESULTS AND DISCUSSIONS}

\section{Results}

\section{Normality Test Results}

The Normality test in this study using the Kolmogorov-Smirnov method used to determine whether a data followed a normal distribution or not based on its significance.

If Asymp.Sig (2-tailed) $>0.05$ then residual data is normally distributed If Asymp.Sig (2-tailed) $<0.05$ then residual data is not normal.

Table 2: Normality Test Results

One-Sample Kolmogorov-Smirnov Test

\begin{tabular}{llr} 
& & \multicolumn{2}{c}{$\begin{array}{c}\text { Unstandardized } \\
\text { Residual }\end{array}$} \\
\hline $\mathrm{N}$ & & 86 \\
\hline Normal Parameters & & a,b \\
\cline { 2 - 3 } & Mean & 3,29760027 \\
\hline Most Extreme Differences & Std. Deviation & .066 \\
\cline { 2 - 3 } & Absolute & .051 \\
\hline
\end{tabular}


Sobana, D. H., \& Anjani, M. S. | Determinant of Interest_

\begin{tabular}{lrr}
\hline & Negative & -.066 \\
\hline Test Statistic & .066 \\
\hline Asymp. Sig. (2-tailed) & $.200^{\mathrm{c}, \mathrm{d}}$ \\
\hline
\end{tabular}

a. Test distribution is Normal.

b. Calculated from data.

c. Lilliefors Significance Correction.

$\mathrm{d}$. This is a lower bound of the true significance.

Source: SPSS 26 output (data processed by researchers)

Based on table 2 above it is seen that the value of Asymp. Sig. (2-tailed) by $0.200>0.05$. Therefore, Ho cannot be denied. That means standardized residual values are declared to spread normally or in other words normal distribution.

\section{Multicollinearity Test Results}

A good regression model should not occur correlations among free variables. The way to test the symptoms of multicollinearity in a regression model is to look at the values of Tolerance (TOL) and Variance Inflation Factor (VIF). If the tolerance value $>0.10$ or VIF < 10 , then the model is declared no symptoms of multicollinearity.

Table 3: Multicollinearity Test Coefficients $^{\mathrm{a}}$

\begin{tabular}{llrrr} 
& & \multicolumn{2}{c}{ Collinearity Statistics } \\
Model & & Tolerance & VIF \\
\hline 1 & Motivation to avoid Riba & .478 & 2.093 \\
\cline { 2 - 4 } & Product Knowledge & .478 & 2.093 \\
\hline
\end{tabular}

a. Dependent Variable: Minat

Source: SPSS 26 output (data processed by researchers)

Based on table 3 above, tolerance values in independent variables show numbers greater than 0.10 which is $0.47>0.10$ and VIF values smaller than 10.00 which is $2.093<10.00$. Thus there are no symptoms of multicollinierity between independent variables. This indicates the absence of a linear relationship between the motivation variables of avoiding riba and product knowledge, so further analysis can be done using multiple regression methods.

\section{Heterocedasticity Test Results}

Heteroskedasticity tests using graph analysis have several disadvantages, including subjective judgment. For that, a statistical test is needed that can guarantee the accuracy of the results. In this study, glejser tests were also conducted to detect the absence or absence of heteroskedasticity. The symptoms of heteroskedasticity are indicated by the regression coefficient of each free variable against its residual absolute value. If the probability value is greater than the alpha value (Sig. > 0.05), then it is certain that the model does not contain symptoms of heteroskedastisity. 
Sobana, D. H., \& Anjani, M. S. | Determinant of Interest_

Table 4: Heteroskedasticity Test Results (Glejser Method)

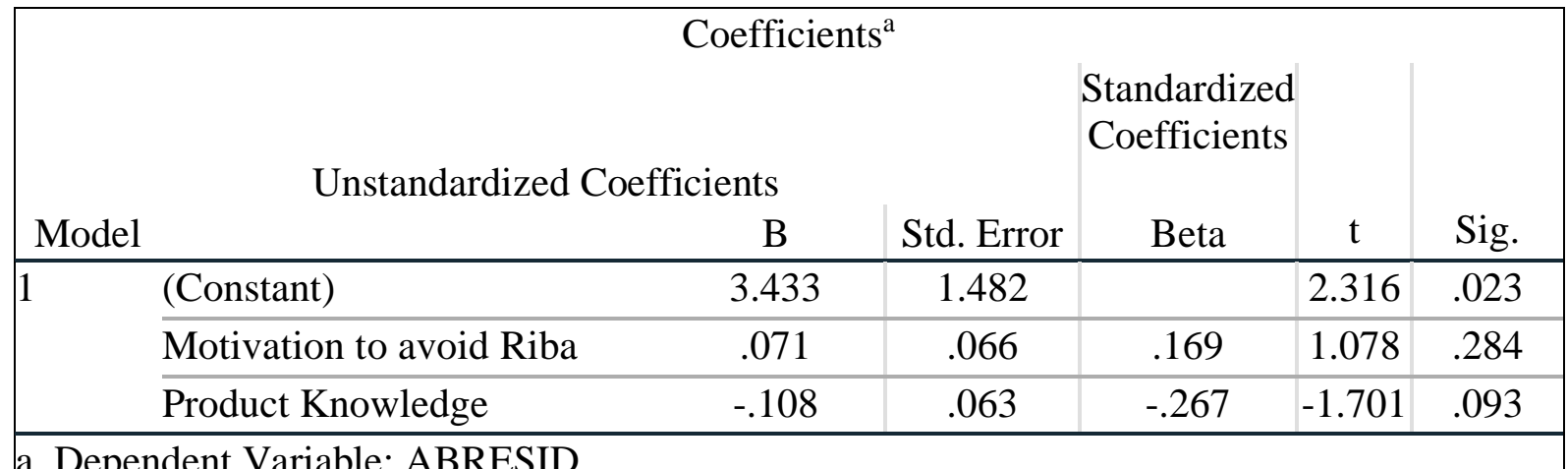

Source: SPSS 26 output (data processed by researchers)

Based on table 4 above it is known that in regression models there are no symptoms of heteroskedasticity. It's because of Sig. Independent variables are greater than alpha values, i.e. the significance of the variable Motivation avoids Riba against residual absolutes of $0.284>$ 0.05 and the significance of product knowledge variables to absolute residuals of $0.093>0.05$.

\section{Descriptive Statistical Analysis}

According to (Sujarweni, 2015)Descriptive statistics in research are basically tabulations presenting summaries, arrangements, and preparation of data in the form of maximum values, minimum values, average values, standard deviation values.

Table 5: Descriptive Statistics

Descriptive Statistics

\begin{tabular}{|c|c|c|c|c|c|}
\hline & $\mathrm{N}$ & Minimum & Maximum & Mean & Std. Deviation \\
\hline Motivation to avoid Riba & 86 & 10 & 45 & 39,07 & 5,034 \\
\hline Product Knowledge & 86 & 11 & 45 & 36,93 & 5,103 \\
\hline Interest & 86 & 9 & 45 & 38,07 & 5,731 \\
\hline Valid N (listwise) & 86 & & & & \\
\hline
\end{tabular}

Based on table 5 above, the amount of research data on each variable is 86 . On The Motivation to Avoid Riba it is known that the average value is 39.07 , then the minimum value is 10 , and the maximum value is 45 . Furthermore Product Knowledge has an average value of 36.93, with the minimum value being 11 and the maximum value being 45 . And lastly Interest obtained an average value of 38.07 with a minimum value of 9 and a maximum value of 45 .

\section{Multiple Linear Regression}

Linear regression analysis aims to see the influence of Motivation variables avoiding riba and product knowledge on interests in becoming a Sharia bank customer. 
Sobana, D. H., \& Anjani, M. S. | Determinant of Interest_

Table 6: Multiple Linear Regression Test Results

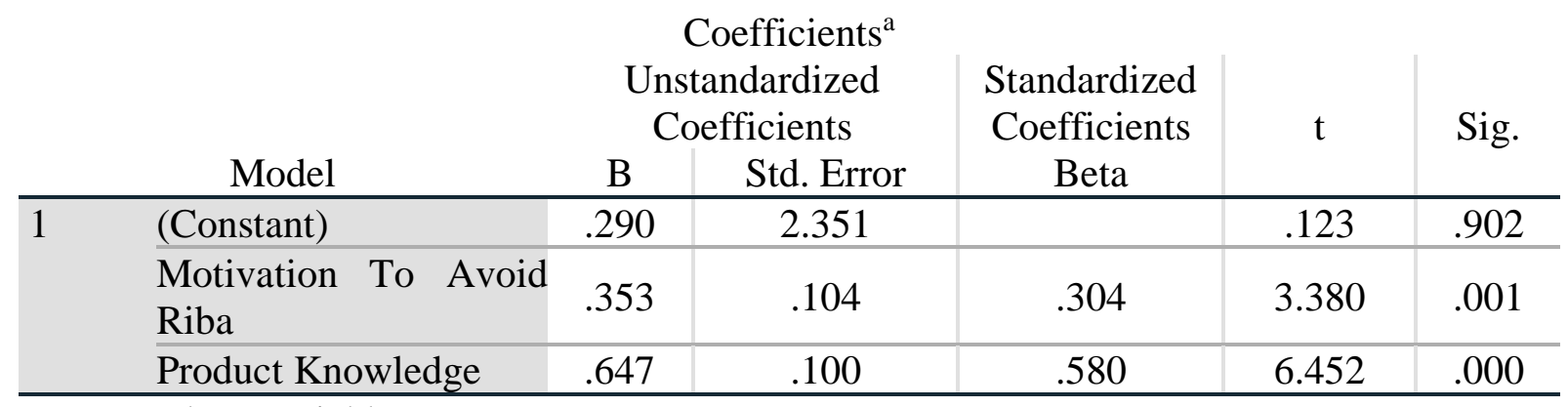

a. Dependent Variable: Interest

Source: SPSS 26 output (data processed by researchers)

Based on the table above, the regression equation is obtained.:

$$
\mathrm{Y}=0.290+0.353 \mathrm{X}_{1}+0.647 \mathrm{X}_{2}+\mathrm{e}
$$

Minat $=0.290+0.353$ Motivasi Menghindari RIba +0.647 Pengetahuan Produk $+\mathrm{c}$

According to the results of the linear regression equation above, it can be formulated that with a constant $(\alpha)$ of 0.290 , shows the value of interest when the motivation avoids riba and product knowledge is worth 0 or fixed at the same time then the interest in being a customer of an Islamic bank is positive value of 0.290. Furthermore, the regression coefficient for motivation to avoid riba is positive value of 0.353 meaning that any addition of motivation to avoid riba by one unit will result in increased interest in becoming a customer of Islamic bank by 0.353 , assuming the variable of constant product knowledge and vice versa. So that the motivation to avoid riba has a positive influence on the interest of being a customer of islamic banks. This indicates, when the motivation to avoid riba increases it will have an impact on increasing interest in becoming a customer of Islamic banks.

Then, product knowledge is positive value of 0.647 , meaning that each addition of product knowledge of one unit will result in increased interest in becoming a customer of Islamic banks by 0.647 , assuming the motivation variable avoids constant riba and vice versa. So that product knowledge has a positive influence on the interest of being a customer of Islamic banks. This indicates, when product knowledge increases it will have an impact on increasing interest in becoming a customer of Islamic banks..

\section{Test $t$}

Partial hypothesis testers use the t test, where to find out whether the motivation to avoid riba and product knowledge separately (partially) affects the interest of being a customer of a Islamic bank The statistical results using SPSS can be seen in the table. Here the researcher presents a comparison of $\mathrm{t}$-count results with t-tables:

Table 7: Comparison of t-tables and t-counts

\begin{tabular}{|c|c|c|c|c|}
\hline Variable & t-count & t-table & sig & probability \\
\hline $\begin{array}{c}\text { Motivation to } \\
\text { Avoid Riba }\end{array}$ & 3.380 & 1.992 & .001 & 0.05 \\
\hline $\begin{array}{c}\text { Product } \\
\text { Knowledge }\end{array}$ & 6.452 & 1.992 & .000 & 0.05 \\
\hline
\end{tabular}

Source: SPSS 26 output (data processed by researchers) 
Based on the results of statistical tests in table 7 , the motivation variable avoiding riba obtained a t-count value of 3,380 with a significance value of 0.001 . The $t$-count value is greater than the table's $t$ value ( $\mathrm{t}$-count $>\mathrm{t}$-table) which is 3,380 > 1,992 and sig value. The motivation variable of avoiding riba is less than $0.05(0.001>0.05)$. The results showed that $\mathrm{H} 1$ was accepted, thus partially the motivation of avoiding riba had a significant effect on the interest of being a customer of an Islamic bank.

Based on the results of statistical tests on product knowledge variables obtained a $t$ calculated value of 6,452 with a significance value of 0.000 . The $t$-count value is greater than the table's t value ( $\mathrm{t}$-count $>\mathrm{t}$-table) which is 6,452>1,992 and sig value. Product knowledge variables are smaller than $0.05(0,000>0.05)$. The results showed that $\mathrm{H} 2$ was accepted, thus partially knowledge of the product had a significant effect on the interest of being a customer of an Islamic bank.

\section{Test $F$}

The $\mathrm{F}$ test is used to look at the influence of motivation to avoid riba and product knowledge simultaneously (simultaneously) on the interest of becoming a customer of an Islamic bank in FEBI Suryakancana University'sstudents. The statistical results using SPSS can be seen in table 9 below:

Table 8: Test Results F

\begin{tabular}{|c|c|c|c|c|c|c|}
\hline \multicolumn{7}{|c|}{$\operatorname{ANOVA}^{a}$} \\
\hline \multicolumn{2}{|c|}{ Model } & Sum of Squares & $\mathrm{df}$ & Mean Square & $\mathrm{F}$ & Sig. \\
\hline 1 & Regression & 1919.261 & 2 & 959.631 & 88.506 & $.000^{b}$ \\
\hline & Residual & 889.092 & 82 & 10.843 & & \\
\hline & Total & 2808.353 & 84 & & & \\
\hline
\end{tabular}

a.Dependent Variable:Interest

b.Predictors: (Constant),Product Knowledge,Motivation To Avoid Riba

Source: SPSS 26 output (data processed by researchers)

The significance level used is 0.05 with an F-table provision of 3.1000. Referring to the SPSS output table above, it is known that the motivation to avoid riba and product knowledge affects the interest of becoming a customer of Islamic banks simultaneously by obtaining an Fcount value of 88,506 with a significance value of 0.000 . The F-count value is greater than the F-count value of the table (F-count $>$ F-table) which is 88,506 > 3,100 and sig value. Smaller than $0.05(0.000>0.05)$. The results showed that $\mathrm{H} 3$ was accepted, thus simultaneously the motivation of avoiding riba and product knowledge had a significant effect on the interest of being a customer of islamic banks.

\section{Determination Coefficient Test (R2)}

The coefficient of determination aims to see the magnitude of the contribution to a free variable together to the variable tied to it by looking at the magnitude of the total determination coefficient (R2). The results of the coefficient of determination test in this study can be seen in the following table. 
Sobana, D. H., \& Anjani, M. S. | Determinant of Interest_

Table 9: Results of the Coefficient of Determination Test

\begin{tabular}{|c|c|c|c|c|}
\hline \multirow[b]{2}{*}{ Model } & \multicolumn{3}{|c|}{ Model Summaryb } & \multirow{2}{*}{$\begin{array}{l}\text { Std. Error of the } \\
\text { Estimate }\end{array}$} \\
\hline & $\mathrm{R}$ & R Square & Adjusted R Square & \\
\hline 1 & $.827^{\mathrm{a}}$ & .683 & .676 & 3.29281 \\
\hline
\end{tabular}

a. Predictors: (Constant), Product Knowledge, Motivation To Avoid Riba

b. Dependent Variable: Interest

Source: SPSS 26 output (data processed by researchers)

In table 9 above the coefficient of determination or R Square is obtained by 0.683 or $68.3 \%$. This shows that the motivation to avoid riba and product knowledge has an effect on the increase and decrease in interest in sharia bank customers in FEBI Unsur students by $68.3 \%$ and the remaining $31.7 \%$ is influenced by other variables not used in this study. While the number $\mathrm{R}$ (correlation) is worth 0.827 means that the relationship between independent variables with dependent variables can be known and very strong and close because it is at intervals approaching 1.

To find out how much influence the independent variable (X1) contributes to the dependent variable (Y) it can be calculated using the effective donation method (SE). SE is a measure of the contribution of an independent variable to a dependent variable in regression analysis.

Table 10: Effective Donation Calculation

\begin{tabular}{|l|l|l|l|}
\hline Variabel & KoefisienRegresi(Beta) & $\begin{array}{l}\text { Correlation Coefficient } \\
\text { (r) }\end{array}$ & R Square \\
\hline $\mathrm{X} 1$ & 0,304 & 0,723 & 0,683 \\
\hline $\mathrm{X} 2$ & 0,580 & 0,800 & 0,683 \\
\hline
\end{tabular}

Source: SPSS 26 output (data processed by researchers)

From the data in table 10, it is used to perform SE calculations using the following formulas::

$\mathrm{SE}(\mathrm{X}) \%=$ Beta $_{\mathrm{x}} \times$ Koefisien $\times 100 \%$ or

$\mathrm{SE}(\mathrm{X}) \%=\operatorname{Beta}_{\mathrm{x}} \times \mathrm{r}_{\mathrm{xy}} \times 100 \%$

Calculation of effective contributions of motivation variables avoids riba against the interest of becoming a customer of Islamic bank as follows:

$\operatorname{SE}\left(\mathrm{X}_{1}\right) \%=$ Beta $_{\mathrm{x} 1} \times \mathrm{r}_{\mathrm{xy}} \times 100 \%$

$\operatorname{SE}\left(\mathrm{X}_{1}\right) \%=0,304 \times 0,723 \times 100 \%$

$\mathrm{SE}\left(\mathrm{X}_{1}\right) \%=21.9 \%$

While the calculation of effective contributions of product knowledge variables to the interests of becoming a customer of Islamic banks as follows:

$\mathrm{SE}\left(\mathrm{X}_{2}\right) \%=\operatorname{Beta}_{\mathrm{x} 2} \times \mathrm{r}_{\mathrm{xy}} \times 100 \%$

$\mathrm{SE}\left(\mathrm{X}_{2}\right) \%=0.580 \times 0.800 \times 100 \%$

$\operatorname{SE}\left(\mathrm{X}_{2}\right) \%=46.4 \%$ 
Sobana, D. H., \& Anjani, M. S. | Determinant of Interest_

\section{DISCUSSION}

\section{The Influence of Motivation to Avoid Riba on The Interest of Becoming a Sharia Bank Customer in FEBI Suryakancana University's Students}

Motivation according to (Schiffman \& Kanuk, 2000) is a driver that converts energy in a person into the form of real activities to achieve certain goals. The motivation of avoiding usury is the internal and external impulse in a person to avoid the danger of usury or bank interest that has been banned by Allah with the aim of being able to initiate transactions that are more halal and do not conflict with Islamic economic principles.

Based on the results of research, the motivation to avoid riba has a significant influence on the interest of being a customer of Islamic bank in FEBISuryakancana University'sstudents. This can be shown from the results of the t-count table $>\mathrm{t}$-table which is 3,380 >1,992 and sig value. The motivation variable of avoiding riba is smaller than $0.05(0.001>0.05)$. This means partially the motivation of avoiding riba has a significant effect on the interest of being a customer of an Islamic bank. Effective contribution of motivation to avoid riba against interest in becoming a customer of Islamic bank by $21.9 \%$.

The results of this study support the results of research conducted by (Irwanti, 2020) stated that the motivation to avoid riba has a significant influence on the interest of becoming a customer of Islamic banks. Another study, (Kholila, 2018) and (Chalimi, 2020) stated that the motivation to avoid riba has an effect on the decision to become a customer of Islamic banks positively. While research conducted by (Putri, Fasa, \& Suharto, 2021) showed that the motivation to avoid riba had no effect on the decision of students to become customers. So, it can be concluded that the results of the study strengthen the theory that the motivation to avoid riba has a positive and significant influence on the interest of being a customer of Islamic banks. But basically, the motivation to avoid riba is completely unmeasurable and cannot be used as a benchmark in choosing Islamic banks because it is private or individual.

\section{The Influence of Product Knowledge on Interest in Becoming a Customer of a Sharia BankCustomer in FEBI Suryakancana University's Students}

Product knowledge according to (Sumarwan, 2003) is a collection of various information about the product. Knowledge is influenced by several factors, one of which is experience. The more experience gained from ourselves and others, the more knowledge we gain. Likewise, about product knowledge, the more knowledge and information about the product owned by consumers, the faster consumers will decide the purchase of a product.

Based on the results of product knowledge research has a significant influence on the interest of being a customer of Islamic bank in FEBI UNSUR students. This can be shown from the results of the t-count table $>\mathrm{t}$-table which is 6,452 >1,992 and sig value. Product knowledge variables are smaller than $0.05(0,000>0.05)$. Thus partially product knowledge has a significant effect on the interest of being a customer of islamic banks. This means that partially product knowledge has a significant effect on the interest of being a customer of an Islamic bank. Effective contribution of product knowledge to interest in becoming a customer of Islamic bank by $46.4 \%$.

Therefore, it is concluded that one's product knowledge can increase interest in becoming a customer of an Islamic bank, but basically product knowledge cannot be used as a benchmark in choosing an Islamic bank because it is individual, knowledge obtained from the results of the meeting and the results of thinking a person individually with different levels of ability in each 
Sobana, D. H., \& Anjani, M. S. | Determinant of Interest_

individual. However, if the knowledge of products about Islamic banks has a high level will have a positive effect on the interest of someone in becoming a customer of an Islamic bank.

The results of this study support research conducted by (Kholila, 2018), (Ade Indra Permana, Sugeng Lubar Prastowo, and Ernie Mardiany Djaenudin, 2021), (Fitria, Sumadi, Ramdani, 2021), (Sumarno, Nawawi, \& Saeki, 2021), (Laeli, 2021), (Sari, 2021) and (Nurbaiti, Supaino, \& Fadhilah, 2020) expressed product knowledge that influenced the decision to become sharia bank customers positively.

\section{The Influence of Motivation to Avoid Riba and Interest in Becoming a Customer of Sharia BankCustomer in FEBI Suryakancana University's Students}

Based on the results of simultaneous tests the magnitude of the influence of motivation variables avoiding usury and product knowledge of customer interest is taken from the value of the R Square coefficient of $68.3 \%$ with the value $\mathrm{F}$ calculated $>\mathrm{F}$ table which is $88,506>3.11$ and the significance value of $0.000<0.05$, thus it can be concluded that $\mathrm{Ha} 3$ was accepted and Ho3 was rejected. So that there is a significant simultaneous influence between the motivation variables of avoiding riba and product knowledge of the interest of being a customer in a Sharia bank in FEBI UNSUR students.

Based on simultaneous statistical testing, the motivational variables of avoiding riba and product knowledge have a significant influence on the interest of being a customer. That is, any increase and decrease in motivation to avoid riba and product knowledge will affect the increase and decrease in interest in becoming customers of Islamic banks..

Other factors also affect the interest in becoming customers according to the theory of the research results of (Selly Nur Ramdan, 2020) and (Uniyanti, 2018).:

\section{Quality of Service}

From the results of selly Nur Ramdan research (2020) based on the regression coefficient of service quality partially positively and significantly affect the interest of being a customer in islamic banks. Based on the hypothesis proposed, ha quality of service has a positive and significant effect on the interest of being a customer in Islamic banks, indicated by the value of $\mathrm{t}$ calculated $>\mathrm{t}$ table which is 5,857> 2,021 then it can be concluded that Ha is accepted. That is, if the quality of service provided by the bank is good and in accordance with customer expectations, interest in becoming a customer will increase..

\section{Income/Pocket Money}

From the results of Uniyanti research (2018) based on the regression coefficient of income / pocket money variables have a positive and significant effect on the interest of customers saving in Islamic banks. The results showed a thitung value of 4,000 with a table t of 1,661. So it can be concluded that Ha is accepted, meaning that income / pocket money has a positive and significant effect on the interest of customers saving in Islamic banks..

\section{Promotion}

From the results of sriwulandariNengsi research (2020) showed that promotional factors have a positive and significant effect on the interest in saving in Islamic banks. Evidenced by the value of the promotional regression coefficient of 0.283 states that every promotion made 
Sobana, D. H., \& Anjani, M. S. | Determinant of Interest_

by the bank towards the interest in saving people increases by 1 point, then the interest in saving at Bank BRIS Unit Lero will increase by 0.283 .

\section{Location}

From the results of research Irnawati Indi (2019) showed that the location factor has a positive and significant impact on the lack of interest in people saving in Islamic banks evidenced by a significant value of, 028 . The selection of location has a strategic nature because it determines the achievement of business entities. One of the keys to successful business is location. Determining the location of a bank is one of the important policies. Banks located in strategic locations make it very easy for customers to deal financially.

The results of this study reinforce the results of previous research conducted by (Chalimi, 2020), (Samsudin, 2020), and (Firda, 2020) showed the results that the motivation to avoid riba and product knowledge simultaneously affect the decision to become a bank customer.

\section{CONCLUSION}

Based on the discussion and the results of research that has been done, it can be concluded three things, namely: a) The motivation variable of avoiding riba has a positive and significant effect on the interest of being a customer of Islamic bank in FEBI UNSUR students, so that $\mathrm{H} 1$ is accepted; b) Product knowledge variables have a positive and significant effect on the interest of being a customer of Islamic bank in FEBI UNSUR students, so that H2 is accepted; and c) The motivation variable of avoiding riba and product knowledge has a positive and significant effect simultaneously (together) on the interest of being a customer in an Islamic bank in FEBI UNSUR students, so that $\mathrm{H} 3$ is accepted. The magnitude of the influence of motivation variables to avoid usury and product knowledge on customer interests is $68.3 \%$ and $31.7 \%$ is influenced by other factors beyond the variables studied in this study.

\section{REFERENCES}

Adhadrianty, F. (2020). Pengaruh Motivasi Menghindari Riba, Pengetahuan Produk, Dan Promosi Produk Terhadap Keputusan Menjadi Nasabah Di Pt Bank Tabungan Negara (Persero) Syariah Kantor Cabang Malang (Doctoral dissertation, Universitas Muhammadiyah Malang).

Andrianto, S. E., Ak, M., \& Firmansyah, M. A. (2019). Manajemen Bank Syariah. Penerbit Qiara Media.

Antonio, M. S. I. (2001). Bank Syariah: dari teori ke praktik. Gema Insani.

Bahlia, L. (2021). Pengaruh Pengetahuan Santri Terhadap Minat Produk Bisnis Multi Level Marketing Syariah (Studi Pada Santri Pondok Pesantren Modern Daar El-Kutub Bayah Lebak Banten) (Doctoral dissertation, Uin Smh Banten).

Chalimi, M. N. (2020). Pengaruh motivasi menghindari riba dan pengetahuan produk terhadap keputusan menjadi nasabah: Studi kasus pada Bank BRI Syariah KCP Mojosari Mojokerto (Doctoral dissertation, Universitas Islam Negeri Maulana Malik Ibrahim). 
Sobana, D. H., \& Anjani, M. S. | Determinant of Interest_

Fadhilah, D. (2020). Pengaruh Pengetahuan Terhadap Minat Menabung Masyarakat Pesantren Di Bank Syariah. Jurnal Bilal: Bisnis Ekonomi Halal, 1(2), 31-37.

Fauziah, W. L. (2021). Dampak Riba mendatangkan Kebinasaan: Sebuah Tinjaun Hadis. Jurnal Riset Agama, 1(1), 197-208.

Firdaus, R. (2019). Perbedaan Pandangan Fuqaha Ihwal Bunga Bank dan Riba. EKONOMIKA SYARIAH: Journal of Economic Studies, 3(2), 47-60.

Fitria, E., Sumadi, S., \& Ramdani, E. A. (2021). Pengaruh Motivasi Menghindari Riba Dan Pengetahuan Produk Perbankan Syariah Terhadap Keputusan Menjadi Nasabah Di Bank Jabar Banten Syariah Kcp Ciamis. Syari'ah Economics, 5(1), 1-16.

Hamzah, I., Yusuf, M. S., \& Athmainnah, S. (2021). Konsep Perbankan Syari'ah Dalam Mewujudkan Pembangunan Nasional Yang Berkeadilan (Tinjauan Sosiologi Hukum Islam). Istikhlaf: Jurnal Ekonomi, Perbankan Dan Manajemen Syariah, 3(1), 45-59.

Haryanto, H. R. (2020). Manajemen Pemasaran Bank Syariah (Vol. 212). Duta Media Publishing.

Hermawanto, A. R., \& Dadang, A. (2021). Analisis Atribut Produk Terhadap Keputusan Pembelian Kartu Cellular Xl Di Kota Bandung. Bussman Journal: Indonesian Journal of Business and Management, 1(1), 12-21.

Husna, L. (2021). Pengaruh Pengetahuan, Religiusitas Dan Iklan Terhadap Minat Mahasiswa Menabung Di Bank Syariah (Studi Kasus Mahasiswa Perbankan Syariah Angkatan 2016 Fakultas Ekonomi dan Bisnis Islam Institut Agama Islam Negeri Tulungagung).

Indi, I. (2019). Faktor-Faktor Yang Memengaruhi Minat Masyarakat Menabung Di Bank Syariah (Studi Kasus Pada Masyarakat Di Kecamatan Rappocini Kota Makassar) (Doctoral dissertation, Universitas Negeri Makassar).

Irwanti, M. (2020). Pengaruh Motivasi Menghindari Riba Terhadap Keputusan Menjadi Nasabah Bank Syariah (Studi Kasus Mahasiswa di Fakultas Ekonomi UIN SMH Banten, Untirta, Uniba, Unsera) (Doctoral dissertation, UIN SMH BANTEN).

Istiqomah, L. (2020). Konsep Riba Dalam Al-Qur'an Dan Implikasinya Bagi Perekonomian. An-Nisbah: Jurnal Perbankan Syariah, 1(1), 73-88.

Kholila, S. (2018). Pengaruh motivasi menghindari riba dan pengetahuan produk perbankan syariah terhadap keputusan menjadi nasabah di Bank Muamalat KC Surabaya-Mas Mansyur (Doctoral dissertation, UIN Sunan Ampel Surabaya).

Laeli, F. (2021). Pengaruh Pengetahuan Dan Promosi Terhadap Minat Santri Menabung Di Bank Syariah (Studi Kasus Pondok Pesantren Ar-Ridwan Kalimukti, Kec. Pabedilan, Kab. Cirebon) (Doctoral dissertation, IAIN Syekh Nurjati Cirebon).

Maulidya, A., Saroh, S., \& Zunaida, D. (2021). Pengaruh Experiential Marketing Dan Marketing Mix Terhadap Minat Beli Ulang Konsumen (Studi Kasus Pada Konsumen 
Sobana, D. H., \& Anjani, M. S. | Determinant of Interest_

Semusim Cafe Kota Malang). JIAGABI (Jurnal Ilmu Administrasi Niaga/Bisnis), 10(2), 205-212.

Novitasari, M. (2020). Pengaruh Financial Technology Knowledge Dan Preferensi Transaksi Non Tunai Terhadap Keputusan Menggunakan Produk Jasa Perbankan. Journal of Economics Development Issues, 3(01), 50-60.

Permana, A. I., Prastowo, S. L., \& Djaenudin, E. M. Pengaruh Motivasi Untuk Menghindari Riba Dan Pengetahuan Produk Terhadap Keputusan Menjadi Nasabah (Studi Kasus Pada Bank Mandiri Syariah Kc Malang).

Prakosa, Y. B., \& Tjahjaningsih, E. (2021). Pengaruh Kualitas Produk, Gaya Hidup, dan Pengetahuan Produk Terhadap Proses Keputusan Pembelian Sepeda Lipat di Kota Semarang. INOBIS: Jurnal Inovasi Bisnis dan Manajemen Indonesia, 4(3), 361-374.

Purnamawati, N. L. A., Mitariani, N. W. E., \& Anggraini, N. P. N. (2020). Pengaruh Kualitas Pelayanan, Kualitas Produk Dan Persepsi Harga Terhadap Minat Beli Ulang Di Bandung Collection Kecamatan Kuta Utara, Badung. VALUES, 1(3), 171-181.

Putri, S., Fasa, M. I., \& Suharto, S. (2021). Pengaruh Produk, Pelayanan dan Motivasi Menghindari Riba Terhadap Keputusan Mahasiswa Menjadi Nasabah Bank Syariah. El mudhorib: Jurnal Kajian Ekonomi dan Perbankan Syariah, 2(1), 30-43.

Saeed, A. (1996). Islamic banking and interest: A study of the prohibition of riba and its contemporary interpretation (Vol. 2). Brill.

Samsudin, S. (2020). Pengaruh motivasi menghindari riba dan pengetahuan produk perbankan syariah terhadap keputusan menjadi nasabah di Bank Muamalat cabang (Doctoral dissertation, IAIN Palangka Raya).

Sandala, F. D., Tumbel, A. L., \& Tampenawas, J. L. (2021). Pengaruh Kelompok Referensi, Persepsi Harga Dan Store Atmosphere Terhadap Minat Beli Konsumen Pada Umkm Beenji Cafe Di Sario Kecamatan Sario. Jurnal EMBA: Jurnal Riset Ekonomi, Manajemen, Bisnis dan Akuntansi, 9(1).

Sari, D. T. (2021). Pengaruh Pengetahuan, Lokasi Dan Religiusitas Terhadap Minat Masyarakat Menjadi Nasabah Di Bank Syariah Mandiri Tulungagung (Studi Kasus Desa Wonorejo Kec. Sumbergempol).

Schiffman, L. G., \& Kanuk, L. L. (2000). Consumer behavior.

Suardi, D. (2019). Pandangan Riba Dan Bunga; Perspektif Lintas Agama Dan Perbedaannya Dengan Sistem Bagi Hasil Dalam Ekonomi Islam. Banque Syar'i: Jurnal llmiah Perbankan Syariah, 5(1).

Sumarno, S., Nawawi, R., \& Saeki, J. (2021). Pengaruh Pengetahuan Masyarakat Tentang Perbankan Syariah Terhadap Minat Untuk Memilih Produk Bank Syariah. Ecobankers: Journal of Economy and Banking, 2(2), 75-79.

Sumarwan, U. (2003). Perilaku Konsumen Teori dan Aplikasinya. Ghalia Indonesia. Jakarta. 
Sobana, D. H., \& Anjani, M. S. | Determinant of Interest_

Uno, H. B. (2021). Teori motivasi dan pengukurannya: Analisis di bidang pendidikan. Bumi Aksara.

Copyright Holder:

(C) Sobana, D. H., \& Anjani, M. S.. (2021)

Publication Right:

Talaa : Journal of Islamic Finance

Department of Sharia Financial Management IAIN Sultan Amai Gorontalo, Indonesia

$(\infty))$ BY-SA 